\title{
On the Relation between School Alienation and Social School Climate
}

\author{
Anne Schmid, University of Bern \\ Julia Morinaj, University of Bern \\ Tina Hascher, University of Bern
}

In recent years, scholars have referred to school alienation as a severe problem that affects the socio-emotional and cognitive development of students. In this study, the authors examined how the relationships with teachers and classmates are associated with students' state of alienation from learning, from teachers, and from classmates, applying a cross-sectional research design. Participants included 543 Grade 7 students from the Swiss canton of Bern who took part in the binational research project "School Alienation in Switzerland and Luxembourg (SASAL, 2015-2019)". Results of correlation and multiple regression analyses revealed that the student-teacher and student-student relationships were associated with alienation from school.

\section{Introduction}

Students spend a considerable amount of their lifetime in school settings and are in constant interaction with their teachers and classmates. As a result, schools play a key role in the individual cognitive and socio-emotional development of their students (Altenbaugh et al., 1995; Schulz \& Rubel, 2011). As students progress through their education, not only do school demands evolve, but also the relationships to teachers and peers change (Eccles et al., 1993). At the same time, adolescents' positive emotions and attitudes toward school decrease over time and so does their bonding to school (Hagenauer \& Hascher, 2010; Simons-Morton, 1999). This gradual detachment from school may eventually result in school alienation (SAL), found to be a predictor of school failure and school dropout (e.g., Finn, 1989; Hascher \& Hadjar, 2018).

There is a multitude of sources a multitude of sources which can lead to SAL. Alongside personal aspects such as gender or academic achievement (Hascher \& Hagenauer, 2010; Trusty \& Dooley-Dickey, 1993), aspects of the educational environment may affect SAL. Students who perceive little social support at school, feel controlled by their teachers, or are rejected by their classmates, are more likely to experience sullenness about school and estrangement (Brown et al., 2003; Legault et al., 2006). In other words, students' perceptions of social school climate (SSC), that can be indicated by their social school relationships (Allodi, 2010), might be associated with SAL. For instance, positive relationships with teachers and classmates were found to enhance psychological well-being and school belonging (Aldridge \& McChesney, 2018; Ozgenel et al., 2018), and may thus mitigate negative school factors such as SAL.

SAL is an important research topic as the problematic nature of SAL has been widely recognized. Individuals, schools, and societies encounter a variety of the severe consequences of SAL. Problem behavior in class and lack of educational success (Hadjar et al., 2015) as well as future social isolation and exclusion from society (Brown et al., 2003) can be costs of SAL. It is therefore important to understand how individual and school factors relate to SAL - not only academic achievement - in order to understand the quality of school experiences and education. With regard to contextual aspects, previous SAL research has primarily focused on structural aspects of school such as school size and student composition (e.g., Trusty \& Dooley-Dickey, 1993), whereas aspects of SSC have only occasionally been examined. Although the importance of positive school relationships for school adaptation and well-being has been reported numerous times (e.g., Aldridge \& McChesney, 2018; Crosnoe et al., 2004), there is little research on the association between SSC and SAL. Consequently, the question of how SSC and SAL are associated deserves greater research attention. Moreover, little is known about how sources of SAL can differ in relation to different alienation domains (Hascher \& Hadjar, 2018). The aim of this paper is to address these gaps by focusing on how the student-teacher relationship and student-student relationship as aspects of SSC are related to different domains of SAL. 


\section{Theoretical background}

\subsection{School alienation}

In recent years, the construct of SAL has frequently been examined. While some scholars view SAL as an inevitable aspect of the human condition and adolescent development (e.g., Newmann, 1981; Sidorkin, 2004), the majority refer to its problematic nature being associated with factors that potentially hamper individual development, such as lower levels of well-being (Morinaj \& Hascher, 2019) and health issues (Safipour et al., 2011). Although scientific consensus regarding a definition is lacking, SAL is generally understood to be an individual outlook on school that can have detrimental effects on a student's academic development. Adolescents who are alienated from school are likely to disengage from school (Finn \& Rock, 1997). This may lead to low school achievement, a lack of identification with school, predominant negative emotions about school, and eventually school dropout (Finn, 1989; Hascher \& Hagenauer, 2010). It was found that identification with and bonding to school decrease over time (Simons-Morton, 1999) while SAL increases (Hascher \& Hagenauer, 2010). Accordingly, alienation from school is understood to be a subjective state that goes along with school detachment. Similar to the relative independence of positive and negative emotions (Feldmann, et al., 1998), SAL may not simply be understood to be the opposite of identification and bonding with school. Instead, SAL is a distinct quality of emotional and cognitive evaluation of school, defined as "a specific set of negative attitudes towards social and academic domains of schooling comprising cognitive and affective elements. While the cognitive dimension relates to student appraisals of the school environment, the affective dimension relates to their feelings. These negative attitudes develop and change over time in terms of a state and can solidify into a disposition" (Hascher \& Hadjar, 2018, p. 179). Thus, the specific character of SAL can be described as a gradual process where negative appraisals and emotions develop to dominate positive appraisals and emotions towards school, leading to internal academic distancing.

Alienation may differ according to various aspects of individuals' lives (Dean, 1961). For instance, at school, students may detach from either academic or social aspects (Firestone \& Rosenblum, 1988). These aspects may be described as different domains of school alienation (Hascher \& Hadjar, 2018). Thus, school alienation is a multi-domain concept, composed of at least three school-related domains: first, students may be alienated from the learning content and learning processes at school. These students feel isolated from what they should be involved in - namely learning - and may experience difficulty in developing an identity as a learner (Sidorkin, 2004). They do not see the relevance of school to their current or future life (Mau, 1992), and thus ascribe only little or no meaning to learning. Second, students may find it difficult to bond with their teachers (Altenbaugh et al., 1995). If students perceive their teachers as unsupportive, unfair, or unfriendly (Çağlar, 2013), or the teachers are not capable of meeting their students' needs (Mann, 2005), these students will eventually feel detached and alienated from their teachers. Third, students may feel estranged from their classmates. Students with disruptive behavior in particular are more likely to be socially excluded in class and may therefore experience less social support (Legault et al., 2006). However, if students are isolated from the dominant group of a school, they might be more likely to feel socially supported by a small group of students who belong to a subculture that rejects the goals of the majority. These students may then feel estranged from most of the students at school, but at the same time feel attached to the subculture they consider themselves belonging to (Altenbaugh et al., 1995). Sources of SAL can occur on different levels. At student level, the factors of academic achievement, gender, and school grade are associated with SAL, with low achievers being more alienated than high achievers (Hascher \& Hagenauer, 2010), boys being more alienated than girls (Çağlar, 2013), and students in higher grades being more alienated than students in lower grades (Trusty \& Dooley-Dickey, 1993). At all levels, school climate in general (Schulz, 2011) and the way teachers interact with their students (Mann, 2005) and their classes may contribute to SAL.

To summarize, alienation from school may evolve in regard to three school-related domains, namely learning, teachers, and classmates (Hascher \& Hadjar, 2018). The degree of alienation may vary across domains. For example, students may become alienated from the learning domain but may concurrently feel attached to teachers and classmates. However, if students detach from all three domains, they may eventually become alienated from school in general.

\subsection{School climate}

In the literature, there is general agreement that school climate refers to "the quality and character of school life" (Cohen et al., 2009, p. 180). This broad definition includes all interpersonal interactions in a school, the norms and values as well as the mission of a school. School climate can be assessed on the individual level (an individual 
perception of the school climate), as well as a clustered perception of classes or all students of a school (aggregated to class or school level). Based on the notion that school climate is best observed multi-dimensionally, however, there is no consistency in defining the dimensions that clearly shape the concept of school climate. According to one coherent approach originating in North American literature, school climate may be composed of four dimensions: (1) safety, (2) teaching and learning, (3) social relationships, and (4) environmental structures (e.g., Cohen et al., 2009; Thapa et al., 2013; Wang \& Degol, 2016). The first dimension of school climate - safety reflects the consistency of a school's discipline policies and the extent to which individuals feel protected from physical and socio-emotional harm (Cohen et al., 2009). Teaching and learning practices may be translated to the emphasis placed by a school on academic achievement or the instructional quality perceived by students; and social school relationships - the third dimension of school climate - mirror whether individuals experience supportive and caring ties to teachers and other students (Lee et al., 2017). Relationships between students and teachers, as well as students and their classmates, have previously been noted as shaping the social climate of educational settings (Allodi, 2010), and are henceforth understood to be indicators of SSC. Environmental structures, the fourth school climate dimension, include aspects such as the cleanliness and layout of the school grounds, or the availability and quality of learning material. However, since environmental structures can be considered fixed and may rarely be modified by schools, scholars frequently concentrate on the other three dimensions (e.g., Lee et al., 2017; Maxwell et al., 2017). The dimension of student-teacher and student-student relationships in particular, has been investigated repeatedly. For instance, poor social relationships were recently associated with students' mental health issues such as depression, and with lower levels of overall subjective wellbeing (Aldridge \& McChesney, 2018; Huang et al., 2018). Therefore, individuals' relationships to teachers and other students deserve specific focus with regard to psychological school outcomes. Students' positive perception of school life was previously associated with gender (e.g., female students experience stronger support at school) (Way et al., 2007), higher levels of academic achievement (Maxwell et al., 2017), academic motivation (Eccles et al., 1993), well-being (Aldridge \& McChesney, 2018), and fewer behavioral problems such as bullying or harassment (Turner et al., 2014). Less is known about how the school climate is associated with students' negative attitudes towards school such as SAL.

\subsection{Social school climate and school alienation}

A positive school climate has been confirmed as supporting student engagement, school bonding and identification (Fredricks et al., 2004) as well as serving as a preventive factor of student problem behavior and dropout (Wang \& Degol, 2016). The preventive effect of a positive school climate might be mediated by the prevention of SAL, whereas a negative interpretation of the school reality might lead to SAL, in turn possibly leading to problem behavior and dropout. Similar to the association of school climate and violence in school (Steffgen et al., 2013), SAL can be understood to be an outcome that is influenced by environmental factors such as school climate. There may be a correlation between the student-teacher relationship, that was defined as an "interpersonal result of a complex intersection of student and teacher beliefs, attitudes, behaviors, and interactions with one another" (Hamre \& Pianta, 2006, p. 59), and alienation from teachers. Also, the student-student relationship that can be defined and assessed as the quality of peer interaction in the classroom, peer acceptance, and social support in school (Bear et al., 2011; Lee et al., 2017) and alienation from classmates, could be argued to bear a strong resemblance to one another. However, although they share the connection of the individual students with their social surrounding at school, they are likely to be distinct. Because students evaluate the quality of school life based on individual perceptions as well as students' shared perceptions (Bradshaw et al., 2014), student-teacher relationship and student-student relationship are shaped with reference to the individual as well as the classroom or even school level. SAL, however, is focused on the individual level, because it relates to an individual's evaluation of school experiences resulting from negative feelings and attitudes toward school (Hascher \& Hadjar, 2018). Thus, it can be expected that a student's individual perception of the school climate is relevant for SAL rather than a shared perspective. Positive relationships mirror students' perceptions of how friendly, respectful, caring, and fairly people at their school interact with each other (Lee et al., 2017), whereas alienation from teachers and classmates reflects, at its core, students' detachment and internal distancing from others (Newman \& Newman, 2001). Students may be socially integrated at school and experience positive relationships, but may still not perceive them as meaningful in their own life (Altenbaugh et al., 1995). Thus, students may be alienated from teachers and classmates despite experiencing positive relationships with teachers and other students. Conversely, students may experience little respect and unfair or unfriendly treatment and nonetheless feel attached to teachers and to other students. It is therefore considered that: 
$\mathbf{H}_{1}$ : Students' individual positive perceptions of the student-teacher relationship and alienation from teachers, as well as students' individual positive perceptions of the student-student relationship and alienation from classmates, are independent but intercorrelated constructs.

Students who perceive their teachers as supportive and experience positive peer interactions are more likely to feel attached to teachers and to other students (Ozgenel et al., 2018), motivated to learn and achieve well in school (Wentzel, 2009). However, previous research also indicates a negative association between the concepts of SSC and SAL. Students reporting negative school relationships perceive learning and school as less pleasant and enjoyable than students experiencing positive relationships (Hagenauer et al., 2013). Students with poor relationships at school may experience little enjoyment during their school tasks, may participate less, and thus assign less or no meaning to the content of what they learn (Finn, 1989) that in turn can lead to SAL and alienation from learning that is a socially-embedded core task in school. Furthermore, poor student-teacher and student-student relationships may impede school attachment, which in turn may undermine school bonding and can intensify alienation from school (Maddox \& Prinz, 2003). It is therefore plausible that poor social relationships at school reinforce students' alienation from teachers and from classmates. Because schools contribute to student development (Bronfenbrenner, 1986), poor social school relationships, among other factors, may possibly increase the effect of SAL, whereas positive social relationships may reduce school alienation. Hence, students' state of SAL may be predicted by SSC. Therefore, based on theoretical considerations, this study further addresses the following hypothesis:

$\mathbf{H}_{2}$ : Perceived student-teacher and student-student relationships are predictive of alienation from learning, from teachers, and from classmates.

\section{Methodology}

\subsection{Participants and procedures}

This study was conducted in order to understand how secondary school students' perceptions of SSC are associated with their levels of SAL. We used data from the first wave of the research project School Alienation in Switzerland and Luxembourg (SASAL, 2015-2019). This binational project focused on the development of SAL in primary as well as secondary schools, and addressed the causes and consequences of SAL at different levels. In the present study, we focused on SSC as a possible cause of SAL at school level.

The sample we used was drawn from 17 schools $\left(M_{\text {school }}=33.71\right.$ students $)$ and 30 classes $\left(M_{\text {class }}=18.03\right.$ students) from the canton of Bern in Switzerland, and included 541 Grade 7 students ( $45.2 \%$ male; $M_{\text {age }}=13.0$ years $[S D=.55]$ ) who took part in the first wave of the SASAL project. All secondary schools were informed about the goals of the study and invited to participate. If school principals expressed an interest in participating, classroom teachers were then contacted and invited. Schools and classes took part on a voluntary basis. The school system in the canton of Bern is separated into lower and higher tracks according to achievement; $35.3 \%$ $(n=191)$ were in the lower track and $64.5 \%(n=349)$ in the higher. Trained members of a research team administered a paper-pencil questionnaire to the students. Data collection for the variables presented here took about 15 minutes and was conducted during regular school hours. Students answered on a voluntary basis and were assured complete anonymity and confidentiality in a written parental consent form.

Although only $16 \%$ of the cases had missing values and a total of $1 \%$ of the values were missing, an analysis of the missing data revealed some patterns in questions on the student-teacher relationship. Because the survey was conducted in a school context during regular school hours, it is plausible that alienated students in particular refused to answer some of these questions. This may have led to a biased data set so the data may not have been a thorough representation of the population (Acock, 2005). We therefore conducted a multiple data imputation with 20 imputations, in order to counteract non-response bias and to maintain an acceptable power falloff of the planned analysis of $<1 \%$ (Graham et al., 2007).

\subsection{Instruments}

School alienation was assessed using the School Alienation Scale (SALS) (Morinaj et al., 2017). It is a 24-item inventory, which analyzes primary as well as secondary school students' feelings and thoughts toward learning, teachers, and classmates. Morinaj et al. (2017) tested the construct validity of the SALS by conducting multigroup confirmatory factor analysis. The results indicated similar psychometric characteristics across various groups, that is, members of different groups allocated the same understanding to the items of the construct. 
Furthermore, the analysis generated three factors with eight items each, that represent the three SAL domains, specifically, Alienation from learning (e.g., "I don't find pleasure in learning at school.", "Learning at school is meaningless.", "Learning at school is boring."; $\alpha=.88$ ), Alienation from teachers (e.g., "The teachers get on my nerves.", "I can trust my teachers." (r), "I don't feel well when my teachers are around me."; $\alpha=.79$ ), and Alienation from classmates (e.g., "I don't care about my classmates.", "My classmates get on my nerves.", "I feel like I don't fit in my class."; $\alpha=.83$ ). The students expressed their agreement with the items of all three SAL scales with a response format ranging from $1=$ disagree to $4=$ agree. Positively worded items were coded reversely. We assessed social school climate on two scales: the Student-teacher relationship scale (e.g., "My teachers are fair.", "My teachers take me seriously.", "I feel accepted by my teachers."; $\alpha=.84$ ) and the Student-student relationship scale (e.g., "I don't have many friends in my class.", "My classmates support me when I need help.", "My classmates motivate me." ; $\alpha=.81$ ) (Hagenauer, 2011), each consisting of seven items. The items were scored from $1=$ disagree to 4 = agree and reverse coding was applied for negatively worded items.

Control variables included gender $(0=$ female, $1=$ male $)$ and academic achievement because of their known association with SAL (Hascher \& Hagenauer, 2010; Trusty \& Dooley-Dickey, 1993) and/or student-student relationship and/or student-teacher relationship (Crosnoe et al, 2004; Thapa et al. 2013). Students' academic achievement was assessed using the Grade Point Average (GPA), based on students' grades in mathematics, German (as the main language of instruction in Switzerland), and French (as the first foreign language in Switzerland), $\alpha=.72$. The school grades vary from 1 (the lowest achievement) to 6 (the highest achievement). Because students in the canton of Bern are allocated to different school tracks based on their academic performance, school track $(0=$ Real (lower track), 1 = Sek (higher track)) was also included as a control variable.

\subsection{Statistical analysis}

This study applied a correlational research design following two major analytical steps. Using the Statistical Package for the Social Sciences (SPSS) Software Version 26, the Kolmogorov-Smirnov test was applied prior to statistical analysis, to verify the distribution of the scales. None of the scales of the three SAL domains (Alienation from learning, Alienation from teachers, Alienation from classmates) or the two subscales of SSC (Student-teacher relationship, Student-student relationship) were normally distributed. Because of the relatively big sample, we estimated Pearson correlations despite the non-normal distributed data. Additionally, to verify hypothesis one, a confirmatory factor analysis (CFA) was conducted using the statistical package Mplus version 8 (Muthén \& Muthén, 2012-2018) in order to further analyze whether alienation from teachers and the student-teacher relationship as well as alienation from classmates and the student-student relationship were distinct concepts. More specifically, using CFA, we wanted to test whether the items of the respective construct loaded exclusively or predominantly onto this construct. Also, CFA would identify possible cross-loadings.

To test the second hypothesis and to account for the hierarchically structured data, we conducted multilevel modeling using the SPSS mixed-model procedure. Prior to multilevel modeling we group-mean centered the level 1 predictors to later include them as level 2 variables in the model. An unconditional model was then applied that allowed interclass correlation coefficients (ICC) to be conducted, indicating the variability of scores between classes. Next, models for each dependent variable were tested and student-teacher relationship, studentstudent relationship, gender, school track, and academic achievement were included as first level predictor variables. Last, the previously mean-centered student-teacher and student-student relationship variables were included in the model. The -2 Log Likelihood and Akaike's Information Criterion (AIC) were analyzed to test the model fit for every model.

\section{Results}

\subsection{Descriptive statistics}

The results of the Pearson correlations indicated a moderately significant negative association between students' perceptions of the student-teacher relationship and alienation from learning as well as alienation from classmates. Moreover, a moderately negative relationship was found between students' perceptions of the student-student relationship and alienation from learning as well as alienation from teachers. The studentteacher relationship and alienation from teachers as well as the student-student relationship and alienation from classmates produced a relatively strong negative relation $(r=-.70$ and $r=-.73, p<.01$, respectively). To verify whether alienation from teachers and the student-teacher relationship as well as alienation from classmates and the student-student relationship are conceptually distinct constructs, we conducted a confirmatory 
factor analysis (CFA) including the three SAL domains and the two subscales of SSC using the maximum likelihood estimation with robust standard errors (MLR) to account for non-normally distributed data (Brown, 2015). Model fit was assessed based on several indices, including the ratio of the chi-square statistic to the degrees of freedom $\left(\chi^{2} / d f\right)$, comparative fit index (CFI), root mean square error of approximation (RMSEA), and standardized root mean square residual (SRMR). According to Little (2013), a good fit is indicated by a $\chi^{2} / d f$ value less than 2, a CFI value above 0.90, and RMSEA and SRMR values below 0.08. Following these recommendations, the model yielded a good fit $\left(\chi^{2}=1076.39, d f=633, \chi^{2} / d f=1.70, \mathrm{CFI}=.94\right.$, RMSEA = .03$, SRMR $=.05)$. The results revealed the cross-loading of Item 3 of the alienation from classmates factor ('I feel accepted by my classmates (r).') on the student-student relationship factor and the cross-loading of Item 5 of the student-student relationship factor ('My classmates motivate me') on the alienation from classmates factor. Exclusion of these items did not substantially change the strength of the relationship between the constructs. We further examined the model in which the student-teacher relationship and alienation from teachers, and the student-student relationship and alienation from classmates were combined into one factor. This modification resulted in a significant decrease in model fit $\left(\chi^{2}(7)=144.26, p<.001\right)$, suggesting that the constructs can be considered as conceptually distinct.

The mean values of the two SSC factors $\left(M_{\mathrm{STR}}=3.29, M_{\mathrm{SSR}}=3.41\right)$ were located above the average value of $M=2.5$. Hence, the students perceived their relationships to teachers as well as to other students as somewhat positive. Moreover, the low mean values of the three SAL domains $\left(M_{\mathrm{AL}}=1.83, M_{\mathrm{AT}}=1.57, M_{\mathrm{AC}}=1.51\right)$ indicated that the students experienced generally low levels of alienation.

Table 1

Mean values and intercorrelations between the factors of school alienation and social school climate

\begin{tabular}{lccccc}
\hline Measure & 1 & 2 & 3 & 4 & 5 \\
\hline 1. Alienation from learning & - & & & & \\
2. Alienation from teachers & $.50^{* *}$ & - & & & \\
3. Alienation from classmates & $.23^{* *}$ & $.37^{* *}$ & - & - & - \\
4. Student-teacher relationship & $-.48^{* *}$ & $-.70^{* *}$ & $-.32^{* *}$ & $.26^{* *}$ & 3.42 \\
5. Student-student relationship & $-.15^{* *}$ & $-.23^{* *}$ & $-.73^{* *}$ & 3.29 & .51 \\
M & 1.83 & 1.58 & 1.52 & .46 & .55 \\
SD & .56 & .48 & & .46 \\
\hline
\end{tabular}

Note. $N=541.1-4: 1$ disagree, 4 agree. ${ }^{* *} p<.01$.

\subsection{Multilevel modeling}

We examined further whether the two factors of SSC are predictive of the experienced level of SAL (see Table 2). To account for a two-level hierarchical data structure (i.e., students nested within classrooms), we performed multilevel modeling. We followed Hox (2013) and Peugh and Enders (2005) in interpreting the results of multilevel modeling. On the student level (level 1), we have three SAL domains (Alienation from learning, Alienation from teachers, Alienation from classmates) as outcome variables, two variables of SSC (Student-teacher relationship, Student-student relationship) as explanatory variables as well as three covariates, gender, school track, and GPA. There are data on 541 students in 30 classes, so the average class size is 18 students. The level 1 predictors were group-mean centered, which allowed to test within-class association between each predictor and the outcomes. The group means for these predictors were reintroduced as level 2 variables to account for contextual effects (i.e., class effects) in the model. We firstly examined the effects of the unconditional model (the intercept-only model), which allowed us to compute the proportion of variability in outcome scores (i.e., alienation domains) that exists between level 2 units (i.e., classes). The intraclass correlation coefficient (ICC) indicated that $12 \%$ of total alienation from learning score variability, $13 \%$ of total alienation from teachers score variability, and $18 \%$ of total alienation from classmates score variability occurred between classes. The next model (Model $1_{\mathrm{AL}}$, Model $1_{\mathrm{AT}}$, Model $1_{\mathrm{AC}}$ ) included Student-teacher relationship, Student-student relationship, gender, school track, and academic achievement as predictors at level 1 that have been group-mean centered. In Model $1_{\mathrm{AL}}(F(1,462.70)=90.09, p<.001)$ and Model $1_{\mathrm{AT}}(F(1,462.45)=318.51, p<.001)$, results indicated that the student-teacher relationship was a significant predictor of alienation from learning and alienation from teachers $(\beta=-.38, t(462.70)=-9.49, p<.001$, CI $[-0.53,-0.35]$ and $\beta=-.59, t(462.45)=$ $-17.85, p<.001$, CI $[-0.63,-0.51]$, respectively), whereas the student-student relationship was not. In Model 
$1_{\mathrm{AC}}$, both student-teacher relationship $(F(1,462.70)=13.09, p<.001)$ and student-student relationship $(F(1,462.45)=384.81, p<.001)$ significantly predicted alienation from classmates $(\beta=-.11, t(462.70)=-3.62$, $p<.001$, CI $[-0.16,-0.06]$ and $\beta=-.58, t(462.45)=-19.62, p<.001$, CI $[-0.56,-0.46]$, respectively).

In Model 2, we added the group means for level 1 predictor variables (Student-teacher relationship, Studentstudent relationship), introducing them as level 2 variables (i.e., class intercepts/means). The level 2 models yielded similar pattern of results, indicating that the constructs of Student-teacher relationship and Studentstudent relationship did not change their meaning after aggregation to class level. The level 2 coefficients were therefore not interpreted any further.

To summarize, the ICC and test of the variance component for the unconditional model (i.e., random intercept model) suggested substantial clustering in the data. These findings supported the use of multilevel modelling to analyze the data. Altogether, the results suggest that positive relationships with teachers could be predictive of lower levels of alienation from learning, from teachers, and from classmates, under control of positive relationships with other students, students' gender, school track, and academic achievement. Additionally, positive relationships with other students can predict lower levels of alienation from classmates, while controlling for positive relationships with teachers, students' gender, school track, and academic achievement. Student gender, school track, and academic achievement did not predict alienation from learning, from teachers, or from classmates.

\section{Table 2}

Results of multilevel modeling

\begin{tabular}{|c|c|c|c|c|c|c|}
\hline \multirow[b]{3}{*}{ Predictors } & \multicolumn{2}{|c|}{$\mathrm{AL}$} & \multicolumn{2}{|c|}{ AT } & \multicolumn{2}{|c|}{$\mathrm{AC}$} \\
\hline & Model 1 & Model 2 & Model 1 & Model 2 & Model 1 & Model 2 \\
\hline & $\begin{array}{c}B(\mathrm{SE}) \\
\beta\end{array}$ & $\begin{array}{c}B(\mathrm{SE}) \\
\beta\end{array}$ & $\begin{array}{c}B(\mathrm{SE}) \\
\beta\end{array}$ & $\begin{array}{c}B(\mathrm{SE}) \\
\beta\end{array}$ & $\begin{array}{c}B(\mathrm{SE}) \\
\beta\end{array}$ & $\begin{array}{c}B(\mathrm{SE}) \\
\beta\end{array}$ \\
\hline Intercept & $\begin{array}{c}1.83^{* * *}(.02) \\
-\end{array}$ & $\begin{array}{c}4.70^{* * *}(.05) \\
-\end{array}$ & $\begin{array}{c}1.57^{* * *}(.02) \\
-\end{array}$ & $\begin{array}{c}4.59^{* * *}(.06) \\
-\end{array}$ & $\begin{array}{c}1.51^{* * *}(.02) \\
-\end{array}$ & $\begin{array}{c}4.75^{* * *}(.08) \\
-\end{array}$ \\
\hline STR & $\begin{array}{c}-.44^{* * *}(.05) \\
-.38^{* * *}\end{array}$ & $\begin{array}{c}-.44^{* * *}(.04) \\
-.38^{* * *}\end{array}$ & $\begin{array}{c}-.57^{* * *}(.04) \\
-.59^{* * *}\end{array}$ & $\begin{array}{c}-.58^{* * *}(.03) \\
-.59^{* * *}\end{array}$ & $\begin{array}{c}-.11^{* * *}(.04) \\
-.11^{* * *}\end{array}$ & $\begin{array}{c}-.10^{* * *}(.03) \\
-.11^{* * *}\end{array}$ \\
\hline SSR & $\begin{array}{c}.01(.05) \\
.01\end{array}$ & $\begin{array}{c}.01(.04) \\
.01\end{array}$ & $\begin{array}{c}-.02(.03) \\
.01\end{array}$ & $\begin{array}{c}-.02(.03) \\
.01\end{array}$ & $\begin{array}{c}-.51^{* * *}(.03) \\
-.58^{* * *}\end{array}$ & $\begin{array}{c}-.51^{* * *}(.03) \\
-.58^{* * *}\end{array}$ \\
\hline Gender ${ }^{\mathrm{a}}$ & $\begin{array}{c}.07(.05) \\
.06\end{array}$ & $\begin{array}{c}.08(.05) \\
.06\end{array}$ & $\begin{array}{c}.02(.03) \\
.03\end{array}$ & $\begin{array}{c}.02(.03) \\
.02\end{array}$ & $\begin{array}{c}.05(.04) \\
.05\end{array}$ & $\begin{array}{c}.05(.03) \\
.05\end{array}$ \\
\hline Track $^{b}$ & $\begin{array}{c}-.08(.05) \\
-.03\end{array}$ & $\begin{array}{c}-.07(.04) \\
-.05\end{array}$ & $\begin{array}{c}-.08(.05) \\
-.05\end{array}$ & $\begin{array}{c}-.08(.06) \\
-.05\end{array}$ & $\begin{array}{c}-.02(.05) \\
\quad-.01\end{array}$ & $\begin{array}{c}-.03(.05) \\
-.01\end{array}$ \\
\hline GPAc & $\begin{array}{c}-.01(.05) \\
.00\end{array}$ & $\begin{array}{c}-.01(.04) \\
.00\end{array}$ & $\begin{array}{c}.02(.04) \\
.02\end{array}$ & $\begin{array}{c}.02(.04) \\
.02\end{array}$ & $\begin{array}{c}-.03(.04) \\
-.02\end{array}$ & $\begin{array}{c}-.03(.03) \\
-.03\end{array}$ \\
\hline STR_mean & & $\begin{array}{c}-.85^{* * *}(.10) \\
-.32^{* * *}\end{array}$ & & $\begin{array}{c}-.88^{* * *}(.09) \\
-.39^{* * *}\end{array}$ & & $\begin{array}{c}-.05(.07) \\
-.02\end{array}$ \\
\hline SSR_mean & & $\begin{array}{c}.02(.08) \\
-.01\end{array}$ & & $\begin{array}{c}-.03(.08) \\
-.01\end{array}$ & & $\begin{array}{c}-.91^{* * *}(.07) \\
-.43^{* * *}\end{array}$ \\
\hline Devianced $^{\mathrm{d}}$ & 713.47 & 688.75 & 375.27 & 315.45 & 257.02 & 207.23 \\
\hline$\sigma^{\mathbb{W}_{\mathrm{e}}}$ & $.23(.02)$ & $.23(.02)$ & $.11(.01)$ & $.11(.01)$ & $.09(.01)$ & $.09(.01)$ \\
\hline$\sigma^{\frac{B}{2}} f$ & $.04(.02)$ & $.01(.01)$ & $.04(.01)$ & $.02(.01)$ & $.05(.01)$ & $.01(.01)$ \\
\hline$R^{2}$ & .16 & .26 & .37 & .52 & .39 & .58 \\
\hline
\end{tabular}

Note. $N=541 . B=$ unstandardized regression coefficient. $\beta=$ standardized regression coefficient. $S E=$ standard error. $A L$ alienation from learning, $A T$ alienation from teachers, $A C$ alienation from classmates, STR student-teacher relationship, SSR studentstudent relationship. Significant negative $B$ scores of $S T R$ and $S S R$ on the three dimensions of alienation indicate that positive school relationships predict lower levels of alienation. ${ }^{a}$ Male as reference group. ${ }^{b}$ High achievers as reference group. ${ }^{c} \mathrm{GPA}=$ Grade Point Average (based on students' grades in mathematics, German, and French). d Deviance $=-2$ Log Likelihood. $\sigma^{2 \mathbb{W} e}=$ the variance of the residuals. $\sigma^{\mathrm{B}_{\mathrm{f}}}=$ the variance of the intercepts. ${ }^{* *} p<.01 .{ }^{* * *} p<.001$ 


\section{Discussion and conclusion}

The primary purpose of this study was to investigate how the perceived social climate of a school may be related to experiences of alienation from different school domains, using a cross-sectional correlational research design. Significant associations between the student-teacher relationship as well as the student-student relationship and three SAL domains - alienation from learning, from teachers, and from classmates - could be established. More specifically, the results indicated a strong negative correlation between alienation from teachers and the studentteacher relationship, and between alienation from classmates and the student-student relationship. According to the theoretical outlines on social school climate and alienation theory, these constructs should be considered distinct although intercorrelated. Because the student-teacher relationship and student-student relationship are considered social elements of academic teaching and learning that are based on interactions between individuals and group, they may be related to SAL rather than being aspects of SAL. Two parameters representative of cross-loadings could mean that Item 3 , in addition to measuring alienation from classmates, also measures the student-student relationship; and Item 5, in addition to measuring the student-student relationship, also measures alienation from classmates. These findings attest to the fact that the two items are in need of modification such that they more appropriately load on only one of these two factors.

Consistent with our predictions and previous research, our findings showed that the quality of perceived social school relationships is associated with the experienced level of SAL (Mau, 1989), indicating that as an outcome of school, SAL may be influenced by school climate. Thus, the way students experience their school life, such as their perceptions of the student-teacher relationship as well as the student-student relationship, may lead to alienation from school (Legault et al., 2006; Mann, 2005). In contradiction to our second hypothesis, however, only the student-teacher relationship was predictive of all three alienation domains. First, in line with other research on the student-teacher relationship and learning enjoyment as well as school engagement (Hagenauer \& Hascher, 2010; Roorda et al., 2011), a poor student-teacher relationship may predict alienation from learning. It is therefore likely that other teacher factors, such as poor teaching practices, may contribute to the development of alienation from the learning domain. Second, a poor student-teacher relationship is likely to predict alienation from teachers. If students, for example, do not receive sufficient support from teachers at their school, they may develop alienation toward their teachers. This may then generate problem behavior in class and advance the development of negative perceptions of school that may eventually lead to school dropout (Altenbaugh et al., 1995). Third, the student-student relationship may predict alienation from classmates. This finding is consistent with previous explications on the role of peer support for school belonging (Newmann, 1981). If students feel supported by their classmates, they are more likely to pursue prosocial goals and engage more with other students (Wentzel, 1998). However, alienation may develop if students are members of a peer group showing norms divergent to those of the school (Altenbaugh et al., 1995; Mau, 1989). In regard to the student-teacher relationship, findings showed that the student-teacher relationship was a significant negative predictor of alienation from classmates on the individual level, meaning that the student-teacher relationship is a phenomenon experienced somewhat individually.

The existing body of literature draws attention to gender and academic achievement being related to SAL and school climate (e.g., Hascher \& Hagenauer, 2010; Trusty \& Dooley-Dickey, 1993; Crosnoe et al., 2004, Thapa et al., 2013). Hence, it was considered plausible that gender as well as academic achievement may influence the SSC-SAL relationship. Despite this assumption, our findings indicated that the relationship between SSC and SAL is not affected by students' gender, academic achievement, and their allocation to a specific school track based on their academic performance. However, it has to be taken into account that lower track class sizes in the canton of Bern are generally smaller than those of the higher track. Students in the lower track might therefore spend more time with the same teachers, which may intensify the student-teacher relationship and reduce their level of alienation (Altenbaugh et al., 1995). Our results might thus be different if the lower and higher track classes shared the same contextual properties.

In general, our study revealed rather high scores of positive social relationships and low levels of SAL. Accordingly, the students in our sample experienced their school environment as mostly supportive and respectful and only few students were alienated from school. This could easily lead to the false notion that SAL seems to be less severe than suggested by researchers. However, it is important to keep in mind that the consequences for alienated students and also for society can be long-lasting and severe (Brown et al., 2003). Therefore, the question of how SAL may be caused and prevented by schools is relevant. It has to be recognized that teachers most likely play a key role in the development of SAL (Altenbaugh et al., 1995). Hence, individual teachers in particular may reflect their working processes in terms of creating a beneficial social climate. Schools in general 
may additionally focus on providing school structures that facilitate the development of positive social relationships. They may, for instance, implement a bullying prevention program to strengthen the group identity and create a safe school environment (Schulz, 2011), or they may allow students to give feedback to their teachers in order to create a positive social climate (Barile et al., 2012). Although these recommendations may support schools in containing some of the sources of SAL, it should be noted that SAL is a robust construct and changes would take time (Morinaj \& Hascher, 2019).

Several limitations should be considered when interpreting our results. First, our study is cross-sectional in nature and thus the results do not reveal causal relationships. Additional longitudinal research on the relationship between SSC and SAL is needed that further clarifies and separates the direction from the quality of the relationship, indicating whether SSC and SAL are causes or consequences of each other. Furthermore, randomized sampling was not possible and the multilevel models conducted are only estimates of the observed students. Therefore, the models cannot reproduce the true relatedness and cannot be generalized to the broader public. Hence, the process of the development of SAL, and whether or how schools contribute to it, should receive further attention. Second, similar to research on other socio-emotional constructs, the concepts of SAL and SSC overlap. We therefore recommend that researchers more explicitly elucidate how the constructs of SAL and SSC are defined in their projects and publications. Future research is needed to illustrate how socioemotional constructs related to research in school could be separated. Third, as SAL seems to be experienced on an individual level (Morinaj \& Hascher, 2019), qualitative research designs might be beneficial to gain a more thorough understanding of how schools may cause SAL. It is likely that alienated students who can easily choose not to answer some of the questions in the questionnaire may receive more attention if they were interviewed. Fourth, other school climate factors, such as order and discipline, teaching and learning practices that may include the degree of freedom and autonomy allowed, as well as lived values, should be considered further (Thapa et al., 2013). As previous research suggests, these aspects may conceivably predict SAL (Çağlar, 2013). Fifth, because of patterns in the missing data, we conducted multiple data imputation. Although multiple imputed data in this case might prevent biased estimates (Acock, 2005), some of the values are nevertheless simulated and therefore do not fully reflect the real tendency.

Despite these limitations, this study is a valuable contribution to research for several reasons. Because SAL is a specific quality of how students emotionally and affectively evaluate school, it presents a different view of how students can think and feel about school other than the positively-connoted school belonging and school identification. Students who are not bonded to school are not automatically alienated. Hence, similar to the relative co-existence of positive and negative emotions (Feldmann et al., 1998), there is an added value to investigating SAL and school belonging as well as school identification, because all three concepts may contribute to understanding success and failure in school. Most notably, this is the first study to our knowledge to examine the association between SSC and different domains of SAL. Our results support the notion that different alienation domains can have different associations with various school factors. In other words, alienation from learning, alienation from teachers, and alienation from classmates may have different sources within the same person (Morinaj et al., 2017). Furthermore, little is known about how school factors might be related to it. This gap is addressed by investigating SSC as a possible source of SAL. Therefore, the findings of our study not only contribute to the existing body of research, but also indicate some aspects of school life that might be important in mitigating SAL. To conclude, the results of our study revealed that poor SSC can play an essential role in the development of alienation from school, and therefore deserves attention, not only in research but also in establishing teaching practices.

\section{Acknowledgements}

This study was supported by the Swiss National Science Foundation under Grant 100019L_159979 in Switzerland and the Luxembourg National Research Fund under Grant INTER/SNF/14/9857103 in Luxembourg. 


\section{References}

Acock, A. C. (2005). Working with missing values. Journal of Marriage and Family, 67(4), 1012-1028. https://doi.org/10.1111/ j.1741-3737.2005.00191.x

Aldridge, J. M., \& McChesney, K. (2018). The relationships between school climate and adolescent mental health and wellbeing: A systematic literature review. International Journal of Educational Research, 88, 121-145. https://doi.org/10.1016/j. ijer.2018.01.012

Allodi, M. W. (2010). The meaning of social climate of learning environments: Some reasons why we do not care enough about it. Learning Environments Research, 13(2), 89-104. https://doi.org/10.1007/s10984-010-9072-9

Altenbaugh, R. J., Engel, D. E., \& Martin, D. T. (1995). Caring for kids: A critical study of urban school leavers. Falmer Press. https://doi.org/10.4324/9781315043012

Barile, J. P., Donohue, D. K., Anthony, E. R., Baker, A. M., Weaver, S. R., \& Henrich, C. C. (2012). Teacher-student relationship climate and school outcomes: Implications for educational policy initiatives. Journal of Youth and Adolescence, 41(3), $256-267$. https://doi.org/10.1007/s10964-011-9652-8

Bear, G. G., Gaskins, C., Blank, J., \& Chen, F. F. (2011). Delaware school climate survey-student: Its factor structure, concurrent validity, and reliability. Journal of School Psychology, 49(2), 157-74. https://doi.org/10.1016/j.jsp.2011.01.001

Bradshaw, C. P., Waasdorp, T. E., Debnam, K. J., \& Johnson S. (2014). Measuring school climate in high schools: A focus on safety, engagement, and the environment. Journal of School Health, 84(9), 593-604. http://doi.wiley.com/10.1111/josh.12186

Bronfenbrenner, U. (1986). Alienation and the four worlds of childhood. The Phi Delta Kappan, 67(6), 430-436.

Brown, M., Higgins, K., \& Paulsen, K. (2003). Adolescent alienation: What is it and what can educators do about it? Intervention in School and Clinic, 39(1), 3-9. https://doi.org/10.1177/10534512030390010101

Brown, T. A. (2015). Confirmatory factor analysis for applied research. New York: Guilford Publications.

Çağlar, Ç. (2013). The relationship between the perceptions of the fairness of the learning environment and the level of alienation. Eurasian Journal of Educational Research, 50, 185-206.

Cohen, J., McCabe, E. M., Michelli, N. M., \& Pickeral, T. (2009). School climate: Research, policy, practice, and teacher education. Teachers College Record, 111(1), 180-213.

Crosnoe, R., Johnson, M. K., \& Elder, G. H. (2004). Intergenerational bonding in school: The behavioral and contextual correlates of student-teacher relationships. Sociology of Education, 77(1), 60-81. https://doi.org/10.1177/003804070407700103

Dean, D. G. (1961). Alienation: Its meaning and measurement. American Sociological Review, 26(5), 753-758. https://doi. org/10.2307/2090204

Eccles, J. S., Midgley, C., Wigfield, A., Buchanan, C. M., Reuman, D., Flanagan, C., \& MacIver, D. (1993). Development during adolescence: The impact of stage-environment fit on young adolescents' experiences in schools and in families. American Psychologist, 48(2), 90-101. https://doi.org/10.1037/0003-066X.48.2.90

Feldman Barrett L., \& Russell, J. A. (1998). Independence and bipolarity in the structure of current affect. Journal of Personality and Social Psychology, 74, 976-984. https://doi.org/10.1037/0022-3514.74.4.967

Finn, J. D. (1989). Withdrawing from school. Review of Educational Research, 59(2), 117-142. https://doi. org/10.3102/00346543059002117

Finn, J. D., \& Rock, D. A. (1997). Academic success among students at risk for school failure. Journal of Applied Psychology, 82(2), 221-234. https://doi.org/10.1037/0021-9010.82.2.221

Firestone, W., \& Rosenblum, S. (1988). The alienation and commitment of students and teachers in urban high schools: A conceptual framework. Educational Evaluation and Policy Quarterly, 10, 285-300.

Fredricks, J. A., Blumenfeld, P. C., \& Paris, A. (2004). School engagement: Potential of the concept, state of the evidence. Review of Educational Research, 74(1), 59-109. https://doi.org/10.3102/00346543074001059

Graham, J. W., Olchowski, A. E., \& Gilreath, T. D. (2007). How many imputations are really needed? Some practical clarifications of multiple imputation theory. Prevention Science, 8(3), 206-213. https://doi.org/10.1007/s11121-007-0070-9

Hadjar, A., Backes, S., \& Gysin, S. (2015). School alienation, patriarchal gender-role orientations and the lower educational success of boys. A mixed-method study. Masculinities and Social Change, 4, 85-116. https://doi.org/10.4471/MCS.2015.61

Hagenauer, G. (2011). Lernfreude in der Schule [Learning enjoyment at school]. Waxmann.

Hagenauer, G., \& Hascher, T. (2010). Learning enjoyment in early adolescence. Educational Research and Evaluation, 16(6), 495-516. https://doi.org/10.1080/13803611.2010.550499

Hagenauer, G., Reitbauer, E., \& Hascher, T. (2013). "It's cool but challenging." The relevance of basic need fulfillment for students' school enjoyment and emotional experiences at the transition from primary to secondary education. Orbis Scholae, 7(2), 7-22. https://doi.org/10.14712/23363177.2015.19

Hascher, T., \& Hadjar, A. (2018). School alienation - Theoretical approaches and educational research. Educational Research, 60(2), 171-188. https://doi.org/10.1080/00131881.2018.1443021

Hascher, T., \& Hagenauer, G. (2010). Alienation from school. International Journal of Educational Research, 49(6), $220-232$. https://doi.org/10.1016/j.ijer.2011.03.002

Hamre, B. K., \& Pianta, R. C. (2006). Student-Teacher Relationships. In G. G. Bear \& K. M. Minke (Eds.), Children's needs III: Development, prevention, and intervention (p. 59-71). National Association of School Psychologists.

Hox, J. J. (2013). Multilevel regression and multilevel structural equation modeling. The Oxford handbook of quantitative methods, 2(1), 281-294.

Huang, F. L., Lewis, C., Cohen, D. R., Prewett, S., \& Herman, K. (2018). Bullying involvement, teacher-student relationships, and psychosocial outcomes. School Psychology Quarterly, 33(2), 223-234. https://doi.org/10.1037/spq0000249

Lee, E., Reynolds, K. J., Subasic, E., Bromhead, D., Lin, H., Marinov, V., \& Smithson, M. (2017). Development of a dual school climate and school identification measure-student (SCASIM-St). Contemporary Educational Psychology, 49, 91-106. https:// doi.org/10.1016/j.cedpsych.2017.01.003 
Legault, L., Green-Demers, I., \& Pelletier, L. (2006). Why do high school students lack motivation in the classroom? Toward an understanding of academic amotivation and the role of social support. Journal of Educational Psychology, 98(3), 567-582. https://doi.org/10.1037/0022-0663.98.3.567

Little, T. D. (2013). Longitudinal structural equation modelling. New York: Guilford Press.

Maddox, S. J., \& Prinz, R. J. (2003). School bonding in children and adolescents: conceptualization, assessment, and associated variables. Clinical Child and Family Psychology Review, 6(1), 31-49. https://doi.org/10.1023/A:1022214022478

Mann, S. J. (2005). Alienation in the learning environment: A failure of community? Studies in Higher Education, 30(1), 43-55. https://doi.org/10.1080/0307507052000307786

Mau, R. Y. (1992). The validity and devolution of a concept: Student alienation. Adolescence, 27(107), 731-742.

Mau, R. Y. (1989). Student alienation in a school context. Research in Education, 42(1), 17-28. https://doi. org/10.1177/003452378904200102

Maxwell, S., Reynolds, K. J., Lee, E., Subasic, E., \& Bromhead, D. (2017). The impact of school climate and school identification on academic achievement: Multilevel modeling with student and teacher data. Frontiers in Psychology, 8, 1-21. https://doi. org/10.3389/fpsyg.2017.02069

Morinaj, J., \& Hascher, T. (2019). School alienation and student well-being: A cross-lagged longitudinal analysis. European Journal of Psychology of Education, 34(2), 273-294. https://doi.org/10.1007/s10212-018-0381-1

Morinaj, J., Scharf, J., Grecu, A., Hadjar, A., Hascher, T., \& Marcin, K. (2017). School alienation: A construct validation study. Frontline Learning Research, 5(2), 36-59. https://doi.org/10.14786/flr.v5i2.298

Muthén, L. K., \& Muthén, B. O. (1998-2012). Mplus user's guide (7th ed.). Los Angeles, CA: Muthén \& Muthén.

Newman, B. M., \& Newman, P. R. (2001). Group identity and alienation: Giving the we its due. Journal of Youth and Adolescence, 30(5), 515-538. https://doi.org/10.1023/A:1010480003929

Newmann, F. (1981). Reducing student alienation in high schools: Implications of theory. Harvard Educational Review, 51(4), 546-564. https://doi.org/10.17763/haer.51.4.xj67887u8715t66t

Ozgenel, M., Caliskan Yilmaz, F., \& Baydar, F. (2018). School climate as a predictor of secondary school students' school attachment. Eurasian Journal of Educational Research, 18(78), 1-30. https://doi.org/10.14689/ejer.2018.78.5

Peugh, J. L., \& Enders, C. K. (2005). Using the SPSS mixed procedure to fit cross-sectional and longitudinal multilevel models. Educational and Psychological Measurement, 65(5), 717-741. https://doi.org/10.1177/0013164405278558

Roorda, D. L., Koomen, H. M. Y., Spilt, J. L., \& Oort, F. J. (2011). The influence of affective teacher-student relationships on students' school engagement and achievement: A meta-analytic approach. Review of Educational Research, 81(4), 493-529. https://doi.org/10.3102/0034654311421793

Safipour, J., Schopflocher, D., Higginbottom, G., \& Emami, A. (2011). The mediating role of alienation in self-reported health among Swedish adolescents. Vulnerable Groups \& Inclusion, 2(1), 5805. https://doi.org/10.3402/vgi.v2i0.5805

Schulz, L. (2011). Targeting school factors that contribute to youth alienation: Focused school counseling programs. Journal of Instructional Psychology, 38(2), 75-83.

Schulz, L., \& Rubel, D. J. (2011). A phenomenology of alienation in high school. Professional School Counseling, 14, $286-298$.

Sidorkin, A. M. (2004). In the event of learning: Alienation and participative thinking in education. Educational Theory, 54(3), 251-262. https://doi.org/10.1111/j.0013-2004.2004.00018.x

Simons-Morton, B. G. (1999). Student-school bonding and adolescent problem behavior. Health Education Research, 14(1), 99-107. https://doi.org/10.1093/her/14.1.99

Steffgen, G., Recchia, S., \& Viechtbauer, W. (2013). The link between school climate and violence in school: A meta-analytic view. Aggression and Violent Behavior, 18, 300-309. https://doi.org/10.1016/j.avb.2012.12.001

Thapa, A., Cohen, J., Guffey, S., \& Higgins-D’Alessandro, A. (2013). A review of school climate research. Review of Educational Research, 83(3), 357-385. https://doi.org/10.3102/0034654313483907

Trusty, J., \& Dooley-Dickey, K. (1993). Alienation from school: An exploratory analysis of elementary and middle school students' perceptions. Journal of Research and Development in Education, 26(4), 232-243.

Turner, I., Reynolds, K. J., Lee, E., Subasic, E., \& Bromhead, D. (2014). Well-being, school climate, and the social identity process: A latent growth model study of bullying perpetration and peer victimization. School Psychology Quarterly, 29(3), 320-335. https://doi.org/10.1037/spq0000074

Wang, M.-T., \& Degol, J. L. (2016). School climate: a review of the construct, measurement, and impact on student outcomes. Educational Psychology Review, 28, 315-352. https://doi.org/10.1007/s10648-015-9319-1

Way, N., Reddy, R., \& Rhodes, J. (2007). Students' perceptions of school climate during the middle school years: Associations with trajectories of psychological and behavioral adjustment. American Journal of Community Psychology, 40(3-4), $194-213$. https://doi.org/10.1007/s10464-007-9143-y

Wentzel, K. R. (1998). Social relationships and motivation in middle school: The role of parents, teachers, and peers. Journal of Educational Psychology, 90(2), 202-209. https://doi.org/10.1037/0022-0663.90.2.202

Wentzel, K. R. (2009). Peers and academic functioning at school. In K. H. Rubin, W. M. Bukowski, \& B. Laursen (Eds.), Social, emotional, and personality development in context. Handbook of peer interactions, relationships, and groups (p. 531-547). The Guilford Press.

Keywords: School alienation; social school climate; student-teacher relationship; student-student relationship; secondary education 


\section{Die Beziehung zwischen Schulentfremdung und sozialem Schulklima}

\section{Zusammenfassung}

Schulentfremdung stellt ein Problem für die sozial-emotionale und kognitive Entwicklung von Lernenden dar. In dieser Studie wurde anhand einer Querschnittsanalyse der Zusammenhang zwischen der Schüler-LehrerBeziehung sowie der Schüler-Schüler-Beziehung und drei Schulentfremdungsdomänen (Entfremdung vom Lernen, Entfremdung von Lehrpersonen, Entfremdung von Klassenkameraden) untersucht. Der Datensatz umfasste 543 Lernende der 7. Klasse aus dem Kanton Bern in der Schweiz, welche an der binationalen Studie "Schulentfremdung in der Schweiz und in Luxembourg (SASAL, 2015-2019)“ teilnahmen. Die Ergebnisse der Korrelations- und multiplen Regressionsanalysen deuten darauf hin, dass sowohl die Schüler/-in-LehrpersonBeziehung als auch die Schüler/-in-Schüler/-in-Beziehung mit Schulentfremdung zusammenhängen.

Schlagworte: Schulentfremdung; soziales Schulklima; Schüler/-in-Lehrperson-Beziehung; Schüler/-inSchüler/-in-Beziehung; Sekundarschulbildung

\section{La relation entre l'aliénation scolaire et le climat social à l'école}

\section{Résumé}

L'aliénation scolaire est un problème sérieux pour le développement socio-émotionnel et cognitif des élèves. Dans cette étude transversale, les auteures ont examiné le lien entre les relations élève-enseignant, d'une part, et élève-camarade, de l'autre, et trois domaines d'aliénation scolaire (l'aliénation de l'apprentissage, des enseignants, des camarades de classe). L'ensemble des données comprenait 543 élèves de 7 e année du canton de Berne en Suisse qui ont pris part au projet de recherche binationale "Aliénation scolaire en Suisse et au Luxembourg (SASAL, 2015-2019)». Les résultats des analyses de corrélation et de régression multiple ont révélé que la relation entre les élèves et les enseignant·e.s ainsi qu’entre les élèves et les camarades de classe était associée à l'aliénation scolaire.

Mots-clés : Aliénation scolaire ; climat social de l'école ; relation élève-enseignant.e ; relation élève-élève ; éducation secondaire

\section{La relazione tra alienazione scolastica e il clima sociale scolastico}

Riassunto

Negli ultimi anni, diversi-e studiosi-e hanno evidenziato come l'alienazione scolastica sia un problema serio che influenza lo sviluppo socio-emotivo e cognitivo degli alunni e delle alunne. Applicando un'analisi traversale, in questo studio le autrici hanno esaminato come la relazione con insegnanti e compagni-e di classe si associ con lo stato di alienazione degli allievi e delle allieve verso la scuola, verso gli e le insegnanti e verso i compagni e le compagne di classe. L'insieme dei dati comprende 543 studenti-esse del $7^{\circ}$ anno del Canton Berna in Svizzera che hanno partecipato allo studio binazionale "Alienazione scolastica in Svizzera e nel Lussemburgo (SASAL, 2015-2019)“. I risultati delle analisi di correlazione e di regressione multipla indicano che il rapporto alunno-ainsegnante e alunno-a-alunno-a è associato all'alienazione dalla scuola.

Parole chiave: Alienazione scolastica; clima scolastico sociale; relazione alunno-a-insegnante; relazione alunnoa-alunno-a; educazione secondaria 
Anne Schmid holds a Master degree of Science in Education and a Master of Arts degree in Secondary Education. Research focus: school climate, school alienation, school transitions. University of Bern, Institute of Educational Science, Department of Research in School and Instruction, Fabrikstrasse 8, CH-3012 Bern E-Mail: anne.k.schmid@gmail.com

Julia Morinaj is a postdoctoral researcher. Research focus: well-being in school, school alienation, emotion and motivation. University of Bern, Institute of Educational Science, Department of Research in School and Instruction, Fabrikstrasse 8, CH-3012 Bern

E-Mail: iuliia.morinaj@edu.unibe.ch

Tina Hascher is Professor of Educational Science. Research focus: emotions and motivation in school, wellbeing, school alienation, teacher education. University of Bern, Institute of Educational Science, Department of Research in School and Instruction, Fabrikstrasse 8, CH-3012 Bern

E-Mail: tina.hascher@edu.unibe.ch 